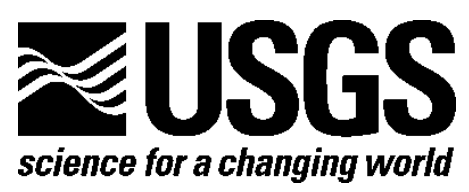

\title{
Coastal Vulnerability Assessment of the Northern Gulf of Mexico to Sea-Level Rise and Coastal Change
}

By E.A. Pendleton, J.A. Barras, S.J. Williams, and D.C. Twichell

Report Series 2010-1146

U.S. Department of the Interior

U.S. Geological Survey 


\section{U.S. Department of the Interior \\ KEN SALAZAR, Secretary}

\section{U.S. Geological Survey \\ Marcia K. McNutt, Director}

U.S. Geological Survey, Reston, Virginia 2010

For product and ordering information:

World Wide Web: http://www.usgs.gov/pubprod

Telephone: 1-888-ASK-USGS

For more information on the USGS-the Federal source for science about the Earth,

its natural and living resources, natural hazards, and the environment:

World Wide Web: http://www.usgs.gov

Telephone: 1-888-ASK-USGS

Suggested citation:

Pendleton, E.A., Barras, J.A., Williams, S.J., and Twichell, D.C., 2010, Coastal Vulnerability Assessment of the Northern Gulf of Mexico to Sea-Level Rise and Coastal Change: U.S. Geological Survey Open-File Report 2010-1146, (Also available at http://pubs.usgs.gov/of/2010/1146/.)

Any use of trade, product, or firm names is for descriptive purposes only and does not imply endorsement by the U.S. Government.

Although this report is in the public domain, permission must be secured from the individual copyright owners to reproduce any copyrighted material contained within this report. 


\section{Contents}

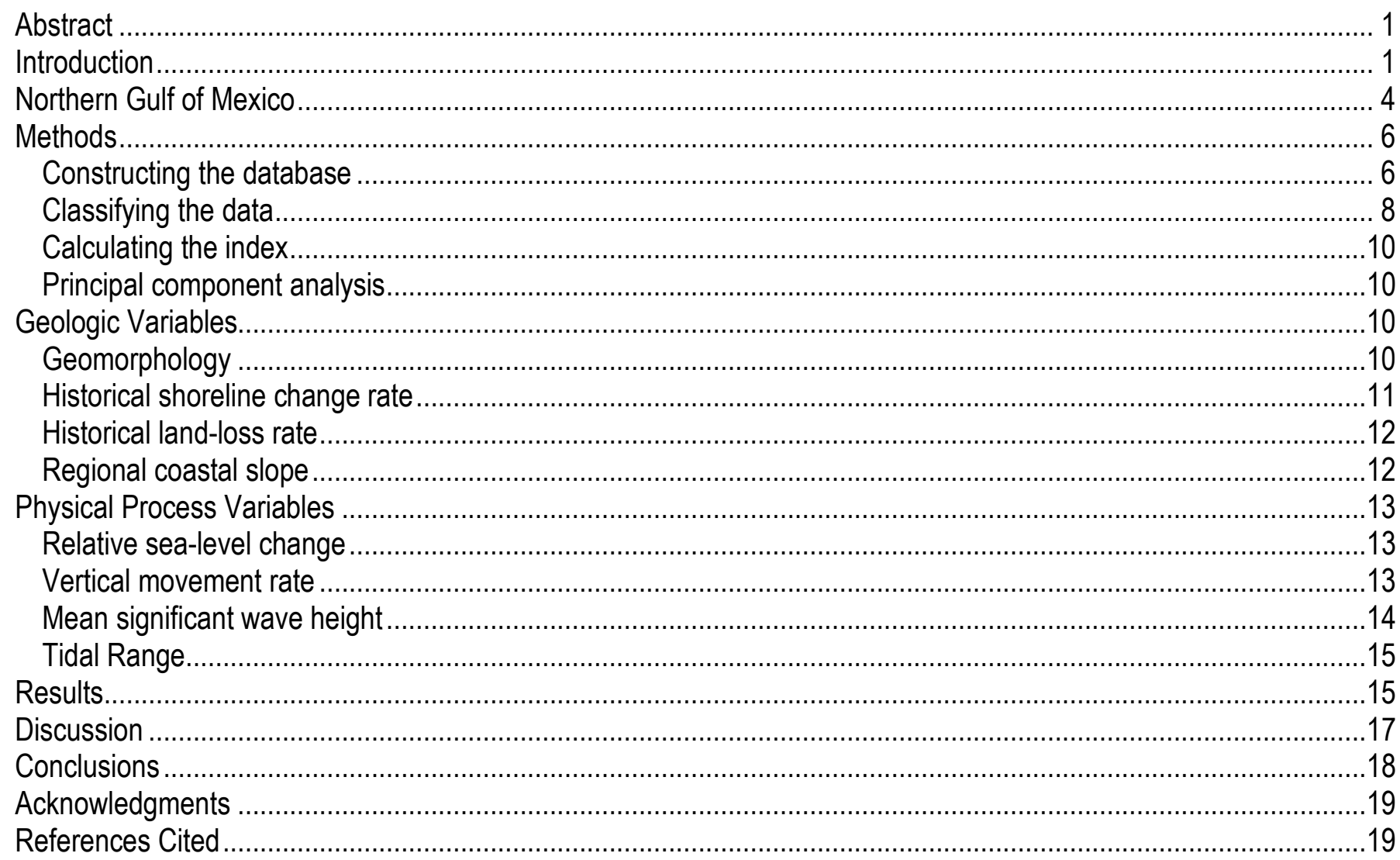

\section{Figures}

Figure 1. Map of the CVI for the U.S. Gulf Coast as determined by Thieler and Hammar-Klose (2000b). The CVI shows the relative vulnerability of the coast to changes due to future rise in sea level...

Figure 2. The Northern Gulf of Mexico study area, stretching from Galveston, TX to just beyond Panama City, FL... 4

Figure 3. The eight geomorphic regions classified by A. Morang (personal communication, January 11, 2010) for the Gulf of Mexico. Image after Andrew Morang, Engineer Research and Development Center, US Army Corps of Engineers.

Figure 4. Coastal geomorphology for the Northern Gulf of Mexico. The colored shoreline represents the variations in coastal geomorphology along the coast. The very high vulnerability geomorphology (red) includes barrier islands, saltmarshes, tidal flats, and sand beaches, whereas high vulnerability areas (orange) include estuaries and lagoons.

Figure 5. Shoreline change and land-area change datasets available within the Northern Gulf of Mexico study area. (A) The Dolan and others (1985) dataset is the most comprehensive and the lowest resolution. It is displayed here as it was categorized by Thieler and Hammar-Kose (2000b). (B) The Miller and others (2004) dataset is available for sandy beaches and barriers along the Gulf of Mexico at 50-meter intervals. (C) The Martinez and others (2006) dataset is for the Gulf Coast of Louisiana.(D) The Barras and others (2008) land-area change data are for Louisiana barriers as well as marsh areas. 
Figure 6. Regional coastal slope for the Northern Gulf of Mexico. The colored shoreline represents the regional slope of the land in a 10-km radius of the shoreline. Very low vulnerability slope areas are along Mobile Bay. Coastal slopes become gentler away from Mobile Bay and thus higher in vulnerability with respect to the CVI ranking scheme (table 2).

Figure 7. Relative sea-level change rate along the Northern Gulf of Mexico. Eight of the 16 tide gage locations along the U.S. Gulf of Mexico coast fall within the study area and are indicated by black dots.

Figure 8. (A) Vertical movement rate along the Northern Gulf of Mexico (after Ivins and others, 2007). The red dots and x's represent GPS locations. (B) Vertical movement rate along the Northern Gulf of Mexico divided into quintiles for CVI variable ranking (table 2).

Figure 9. Mean significant wave height (meters) along the Northern Gulf of Mexico. The black dots indicate the locations of WIS wave stations (Hubertz and others, 1996).

Figure 10.Northern Gulf of Mexico CVI calculated using Dolan and others (1985) shoreline change data and sea-level rise rate from NOS/NOAA water-level gages.

Figure 11. Updated data source CVI calculated using Miller and others (2004), and Martinez and others (2006) shoreline change data, Barras and others (2008) land-area change data, and vertical movement data from Ivins and others (2007).

Figure 12. Updated data source CVI calculated using Miller and others (2004), and Martinez and others (2006) shoreline change data, Barras and others (2008) land-area change data, and vertical movement data from Ivins and others (2007).

\section{Tables}

Table 1. Data sources from the original Gulf of Mexico CVI (Thieler and Hammar-Klose, 2000b) and the updated CVI for the Northern Gulf of Mexico presented here. [Data sources with gray backgrounds were not used to calculate the updated CVI]....

Table 2. Ranges for vulnerability ranking of variables along the Northern Gulf of Mexico Coast.

\section{Conversion Factors}

SI to Inch/Pound

\begin{tabular}{lcl}
\hline \multicolumn{1}{c}{ Multiply } & By & \multicolumn{1}{c}{ To obtain } \\
\hline & Length & \\
\hline millimeter (mm) & 0.03937 & inch (in.) \\
meter (m) & 3.281 & foot (ft) \\
kilometer (km) & 0.6214 & mile (mi) \\
kilometer $(\mathrm{km})$ & 0.5400 & mile, nautical (nmi) \\
meter $(\mathrm{m})$ & 1.094 & yard (yd) \\
\hline & Area & \\
\hline square kilometers $\left(\mathrm{km}^{2}\right)$ & 0.386102159 & square miles (mi2) \\
\hline
\end{tabular}

Vertical coordinate information is referenced to Mean Sea Level (MSL).

Horizontal coordinate information is referenced to the World Geodetic System of 1984 (WGS 84) in a Geographic Coordinate System. 


\title{
Coastal Vulnerability Assessment of the Northern Gulf of Mexico to Sea-Level Rise and Coastal Change
}

\author{
By E.A. Pendleton,J.A. Barras, S.J. Williams, and D.C. Twichell
}

\begin{abstract}
A coastal vulnerability index (CVI) was used to map the relative vulnerability of the coast to future sea-level rise along the Northern Gulf of Mexico from Galveston, TX, to Panama City, FL. The CVI ranks the following in terms of their physical contribution to sea-level rise-related coastal change: geomorphology, regional coastal slope, rate of relative sea-level rise, historical shoreline change rate, mean tidal range, and mean significant wave height. The rankings for each variable are combined and an index value is calculated for 1-kilometer grid cells along the coast. The CVI highlights those regions where the physical effects of sea-level rise might be the greatest. The CVI assessment presented here builds on an earlier assessment conducted for the Gulf of Mexico. Recent higher resolution shoreline change, land loss, elevation, and subsidence data provide the foundation for a better assessment for the Northern Gulf of Mexico. The areas along the Northern Gulf of Mexico that are likely to be most vulnerable to sea-level rise are parts of the Louisiana Chenier Plain, Teche-Vermillion Basin, and the Mississippi barrier islands, as well as most of the Terrebonne and Barataria Bay region and the Chandeleur Islands. These very high vulnerability areas have the highest rates of relative sea-level rise and the highest rates of shoreline change or land area loss. The information provided by coastal vulnerability assessments can be used in long-term coastal management and policy decision making.
\end{abstract}

\section{Introduction}

As part of the Northern Gulf of Mexico (NGOM) Ecosystem Change and Hazard Susceptibility project, the U.S. Geological Survey (USGS) conducted a coastal vulnerability assessment of the impacts of future sea-level change to this coast. This report presents the results of a vulnerability assessment for the Northern Gulf of Mexico from Galveston, TX, to Panama City, FL, and highlights areas that are likely to be most affected by future sea-level rise.

Published analyses of tide gauge data suggest a 20th century mean rate of global sea-level rise (SLR) to be $1.7 \mathrm{~mm} / \mathrm{yr}$ (Bindoff and others 2007). Climate modelers predict a future global rise in sea level of $0.25-0.5 \mathrm{~m}$ by 2100 , which for several carbon emission scenarios is more than double the rate of rise for the 20th century (Meehl and others, 2007). Global SLR estimates from satellite altimeter missions suggest a mean rate of rise of $3 \mathrm{~mm} / \mathrm{yr}$ since 1993 (Milne and others, 2009), and these rates resemble predicted SLR acceleration estimates for the 21st century published by the IPCC (Meehl and others., 2007). The exact rates of present and future global SLR are uncertain; however, the potential coastal impacts of global SLR include shoreline erosion, storm-surge flooding, saltwater intrusion into groundwater aquifers, inundation of wetlands and estuaries, and threats to cultural and historic resources as well as infrastructure (Nicholls and others, 2007).

Expected accelerated global sea-level rise and the response of the coastline have become an area of active research. Although a quantitative tool that accurately predicts coastal response to sea-level rise 
has not yet been perfected due to the complexity of coastal systems, there are many valuable tools that can be utilized including simple inundation models, probabilistic frameworks, and coastal vulnerability assessments. Coastal vulnerability index (CVI) assessments have been used for over a decade to identify areas that may be most vulnerable to impacts of future sea-level rise, and to provide maps and data to support coastal management decisions (Gornitz and others, 1994; Shaw and others, 1998; HammarKlose and Thieler, 2001; Pendleton and others, 2010). The CVI combines the coastal system's susceptibility to change with its natural ability to adapt to changing environmental conditions, yielding a quantitative, although relative, measure of the shoreline's natural vulnerability to the effects of sea-level rise. The methodology focuses on six variables which strongly influence coastal response to sea-level rise:

1. Geomorphology

2. Historical shoreline change rate

3. Regional coastal slope

4. Relative sea-level change

5. Mean significant wave height

6. Mean tidal range

The geologic variables, including geomorphology, historic shoreline change rate, and coastal slope, account for a shoreline's relative resistance to erosion, long-term erosion/accretion trend, and susceptibility to flooding, respectively. The physical process variables, including sea-level change, mean significant wave height, and tidal range, all contribute to the inundation hazards of a particular section of coastline over time scales from hours to centuries. In order to apply this CVI, it is assumed that these six variables are the primary factors responsible for long-term (tens to hundreds of years) coastal change. An obvious omission to long-term coastal change is storms, which are difficult to define as a variable due to their episodic and local nature. CVI results presented in this report are an indication of vulnerability based on coastal processes and geologic qualities that are ever present and predictable. A relatively simple vulnerability ranking system allows these six variables to be incorporated into an equation that produces a coastal vulnerability index. The CVI can be used by scientists and managers to evaluate the likelihood that physical change may occur along a particular shoreline as sea level continues to rise. 
The study presented here builds on an earlier CVI assessment that was calculated for the Gulf of Mexico at 3-minute resolution (Thieler and Hammar-Klose, 2000b) (fig. 1). Recent updates to shoreline change datasets and wetland loss observations as well as subsidence and elevations data increase the resolution of the input data and result in an improved CVI assessment. Here we focus on the Northern Gulf of Mexico from Panama City, FL, to Galveston, TX. This portion of the Gulf of Mexico encompasses some of the most fragile coastal and wetland systems in the United States. Intense storms and high rates of relative sea-level rise, especially along coastal Louisiana, make this region, its infrastructure, ecosystems, and natural resources a primary concern for coastal managers.

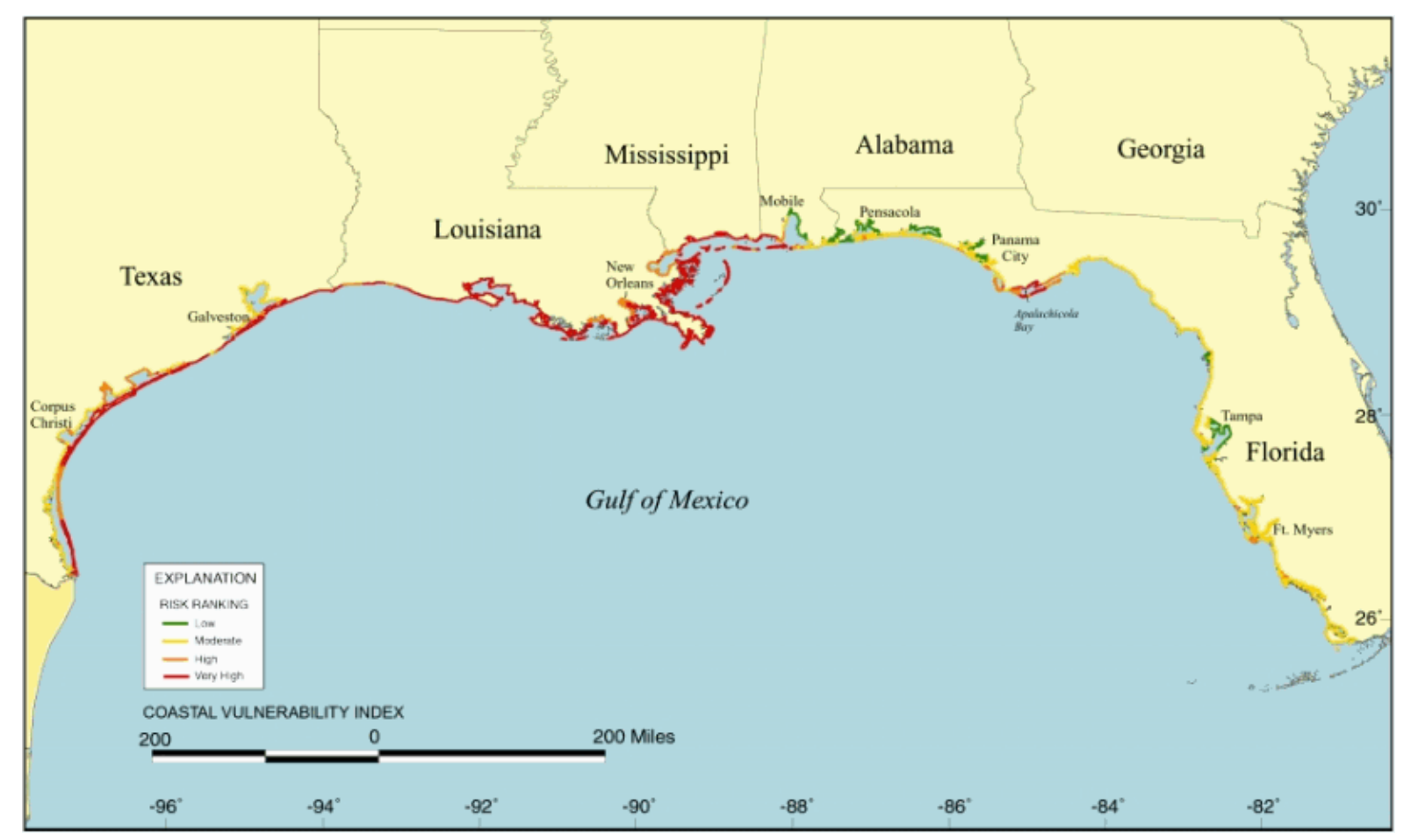

Figure 1. Map of the CVI for the U.S. Gulf Coast as determined by Thieler and Hammar-Klose (2000b). The CVI shows the relative vulnerability of the coast to changes due to future rise in sea level. 


\section{Northern Gulf of Mexico}

The Northern Gulf of Mexico coastline as defined in this study stretches from Galveston, TX, to east of Panama City, FL, spanning approximately 1,200 km of the Gulf of Mexico, not including inland bays (fig. 2). The length of coastline, including coastal bays, totals just less than $11,000 \mathrm{~km}$, based on the GSHHS (global self-consistent, hierarchical, high-resolution shoreline) database (Wessel and Smith, 1996).

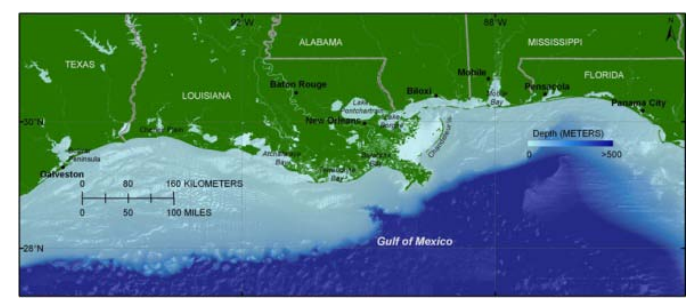

Figure 2. The Northern Gulf of Mexico study area, stretching from Galveston, TX to just beyond Panama City, FL.

The Gulf of Mexico can be divided into morphologic reaches based on wave energy, geology, and lithology (fig. 3). Four of the eight morphologic reaches defined by A. Morang (written communication, January 11, 2010) fall within the Northern Gulf of Mexico CVI study area and are described here. The easternmost morphologic reach stretches from Apalachicola, FL, west through the Mississippi barrier islands, and can be described as relatively sand rich, with numerous barrier islands, and a dominant east to west alongshore transport (fig. 3; G5). Moving westward, the adjacent morphologic reach extends from the end of reach 1 (Pass Christian, MS) to Southwest Pass, LA (fig. 3; G6). This area can be described as being dominated by muddy deltaic sediments delivered by the Mississippi River. Compaction and subsidence of these sediments combined with an inconsistent supply of sediment, due to river avulsion and channelization, have contributed to severe erosion and wetland loss in this area. The third reach covers the Chenier Plain of western Louisiana and eastern Texas to High Island, TX (fig. 3; G7). The Chenier Plain is a marginal-deltaic environment characterized by a muddy substrate with interspersed sand and shell ridges. The last $40 \mathrm{~km}$ of the CVI shoreline defined in this study, lie on the Bolivar Peninsula just north of Galveston, TX (fig. 3; G8). This stretch of coast is dominated by sandy barrier islands enclosing shallow bays. 


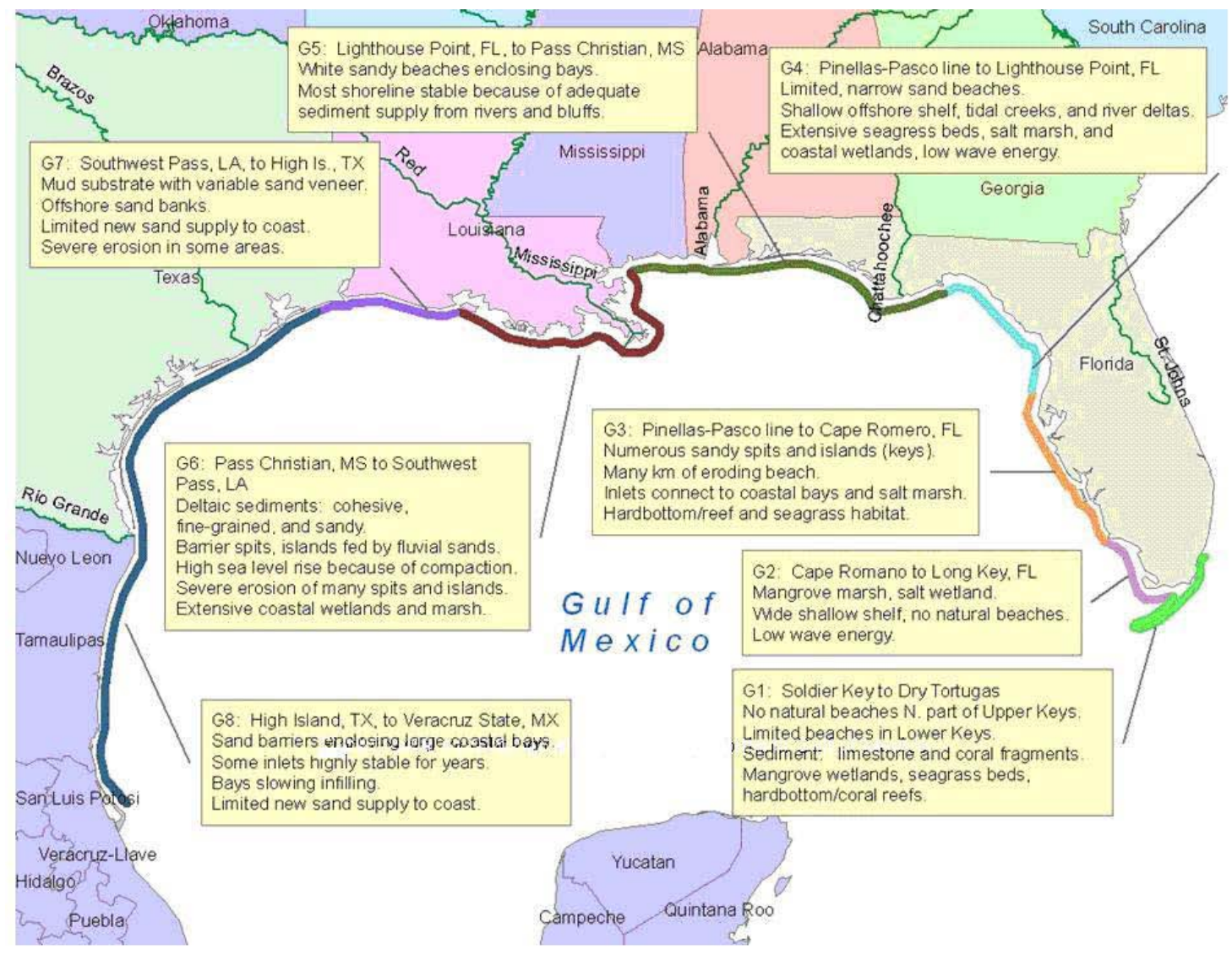

Figure 3. The eight geomorphic regions classified by A. Morang (personal communication, January 11, 2010) for the Gulf of Mexico. Image after Andrew Morang, Engineer Research and Development Center, US Army Corps of Engineers. 


\section{Methods}

\section{Constructing the database}

In order to develop a database for the coastal vulnerability assessment, data for each of the six variables described in the Introduction were gathered from previously published data sources (table 1). The coastal vulnerability databases presented here are based on the methodology used by Thieler and Hammar-Klose (1999) (with a few modifications noted below), which modified the approach of an earlier database developed by Gornitz and White (1992). The CVI database was constructed by dividing the GSHHS for the Northern Gulf of Mexico into approximately 1-km coastal segments (Wessel and Smith, 1996). The GSHHS was used in place of the world vector shoreline (Soluri and Woodson, 1990) employed by Thieler and Hammar-Klose (2000b). Data for each of the six variables (geomorphology, shoreline change, coastal slope, relative sea-level rise, significant wave height, and tidal range) were added to the shoreline attribute table for each coastal segment. Next, each variable in each grid cell was assigned a relative vulnerability value from 1 to 5 (1 is very low vulnerability, 5 is very high vulnerability), which is explained in the next section. In this study recently available datasets related to the shoreline change (Miller and others, 2004; Martinez and others, 2006; Barras and others, 2008), sealevel rise (Ivins and others, 2007), and elevation (Divins and Metzger, 2009) are used to update an earlier CVI database (Thieler and Hammar-Klose, 2000b) (table 1). 
Table 1. Data sources from the original Gulf of Mexico CVI (Thieler and Hammar-Klose, 2000b) and the updated $\mathrm{CVI}$ for the Northern Gulf of Mexico presented here.

[Data sources with gray backgrounds were not used to calculate the updated CVI]

\begin{tabular}{|c|c|c|}
\hline Published data sets & Data Summary & Data Source \\
\hline \multirow[b]{2}{*}{ Shoreline database } & $\begin{array}{l}\text { Global self-consistent, hierarchical, high-resoluiton shoreline shapefile } \\
\text { (http://www.ngdc.noaa.gov/mgg/shorelines/gshhs.html) }\end{array}$ & $\begin{array}{l}\text { (Wessel and } \\
\text { Smith, 1996) }\end{array}$ \\
\hline & $\begin{array}{l}\text { World Vector Shoreline (1:250,000) Data } \\
\text { (http://gcmd.nasa.gov/records/GCMD_WVS_DMA_NIMA.html) }\end{array}$ & $\begin{array}{l}\text { (Soluri and } \\
\text { Woodson } \\
1990)\end{array}$ \\
\hline \multirow[b]{2}{*}{$\begin{array}{l}\text { Landform/Landcover } \\
\text { Information }\end{array}$} & $\begin{array}{c}\text { Orthophotographs, LANDSAT images, landcover shapefiles, and surficial geology } \\
\text { maps provided by LOSCO and/or Google Earth }\end{array}$ & \begin{tabular}{|l} 
(LOSCO, \\
2007; Google \\
Earth, 2009) \\
\end{tabular} \\
\hline & $\begin{array}{l}\text { USGS Coastal Classification Mapping Project (http://coastal.er.usgs.gov/coastal- } \\
\underline{\text { classification/) }}\end{array}$ & \begin{tabular}{|l} 
(Morton and \\
Peterson, \\
2005a-c; \\
Morton and \\
others, 2004, \\
2005)
\end{tabular} \\
\hline $\begin{array}{l}\text { Shoreline change } \\
\text { databases (meters per } \\
\text { year) }\end{array}$ & $\begin{array}{l}\text { The National Assessment of Shoreline Change: A GIS Compilation of vector } \\
\text { shoreline and associated shoreline change data for the U.S. Gulf of Mexico } \\
\text { (http://pubs.usgs.gov/of/2004/1089/) }\end{array}$ & $\begin{array}{l}\text { (Miller and } \\
\text { others, 2004) }\end{array}$ \\
\hline \multirow{3}{*}{$\begin{array}{l}\text { Land-area change maps } \\
\text { (square kilometers per } \\
\text { year) }\end{array}$} & $\begin{array}{l}\text { Shoreline Change History of Coastal Louisiana: 1800's-2005 } \\
\text { (http://www.ladigitalcoast.uno.edu/PDFs/LUIS_ESRI_ShorelineMap_1855- } \\
\text { 2005_11x17.pdf) }\end{array}$ & $\begin{array}{l}\text { (Martinez and } \\
\text { others, 2006) }\end{array}$ \\
\hline & $\begin{array}{c}\text { Coastal erosion and accretion: In the National Atlas of the United States of } \\
\text { America (http://www.nationalatlas.gov/wallmaps 1970.html) }\end{array}$ & $\begin{array}{l}\text { (Dolan and } \\
\text { others, 1985) }\end{array}$ \\
\hline & $\begin{array}{l}\text { Land Area Change in Coastal Louisiana: A Multidecadal Perspective (from } 1956 \text { to } \\
\text { 2006) (http://pubs.usgs.gov/sim/3019/) }\end{array}$ & $\begin{array}{l}\text { (Barras and } \\
\text { others, 2008) }\end{array}$ \\
\hline \multirow{2}{*}{$\begin{array}{l}\text { Regional bathymetry } \\
\text { and topography } \\
\text { (meters) }\end{array}$} & $\begin{array}{l}\text { NGDC } 3 \text { Arc-Second Coastal Relief Gridded Database Volumes 3-5 } \\
\text { (http://www.ngdc.noaa.gov/mgg/coastal/coastal.html) }\end{array}$ & $\begin{array}{l}\text { (Divins and } \\
\text { Metzger, } \\
\text { 2009) }\end{array}$ \\
\hline & $\begin{array}{l}\text { NGDC 2-minute Gridded Global Relief Data (ETOPO2v2) } \\
\text { (http://www.ngdc.noaa.gov/mgg/global/etopo2.html) }\end{array}$ & \begin{tabular}{|l} 
(U.S. \\
Department of \\
Commerce, \\
2006)
\end{tabular} \\
\hline \multirow{2}{*}{$\begin{array}{c}\text { Relative sea-level } \\
\text { change data (milimeters } \\
\text { per year) } \\
\text { and } \\
\text { Vertical land } \\
\text { movement (milimeters } \\
\text { per year) }\end{array}$} & $\begin{array}{l}\text { Regional Trends in Sea-Level } \\
\text { (http://tidesandcurrents.noaa.gov/sltrends/sltrends.shtml) }\end{array}$ & $\begin{array}{l}\text { (NOS/ NOAA/ } \\
\text { COOPS, 2006) }\end{array}$ \\
\hline & $\begin{array}{l}\text { Post-glacial sediment load and subsidence in coastal Louisiana (http://trs- } \\
\text { new.jpl.nasa.gov/dspace/bitstream/2014/40959/1/07-0937.pdf) }\end{array}$ & $\begin{array}{l}\text { (Ivins and } \\
\text { others 2007) }\end{array}$ \\
\hline $\begin{array}{l}\text { Mean significant wave } \\
\text { height stations (meters) }\end{array}$ & $\begin{array}{c}\text { Wave information studies of U.S. coastlines (http://frf.usace.army.mil/cgi- } \\
\text { bin/wis/atl/atl_main.html) }\end{array}$ & $\begin{array}{l}\text { (Hubertz and } \\
\text { others, 1996) }\end{array}$ \\
\hline
\end{tabular}




\section{Classifying the data}

Table 2 shows CVI variables, from both the original Gulf of Mexico CVI and the updated Northern Gulf of Mexico CVI, which include both quantitative and qualitative information. The quantitative variables are assigned a vulnerability ranking based on their actual values, whereas the nonnumerical geomorphology variable is ranked qualitatively according to the relative susceptibility of a given landform to physical change (Thieler and Hammar-Klose, 2000b). Shorelines with erosion/accretion rates between -1.0 and $+1.0 \mathrm{~m} / \mathrm{yr}$ are ranked as moderate. Increasingly higher erosion or accretion rates are ranked as correspondingly higher or lower vulnerability (Thieler and HammarKlose, 2000b). Regional coastal slopes range from very high vulnerability, $<0.30$ percent, to very low vulnerability at values $>1.20$ percent. Here coastal slopes and vulnerability ranges were established using the Coastal Relief Model (3-arc second resolution) (Divins and Metzger, 2009), which replaced the ETOPO-2 (1-minute resolution) dataset used by Thieler and Hammar-Klose (2000b) (U.S. Department of Commerce, 2006). The rate of relative sea-level change is ranked such that rates less than the modern rate of eustatic rise $(1.8 \mathrm{~mm} / \mathrm{yr})$ are very low vulnerability. Since the global or "background" rate is common to all shorelines, the sea-level ranking reflects primarily local to regional isostatic or tectonic adjustment (Thieler and Hammar-Klose, 2000b). Mean wave height contributions to vulnerability range from very low $(<1.1 \mathrm{~m})$ to very high $(>2.6 \mathrm{~m})$ (Thieler and Hammar-Klose, 2000b). Tidal range is ranked such that microtidal $(<1 \mathrm{~m})$ coasts are very high vulnerability, and macrotidal $(>6$ m) coasts are very low vulnerability (Thieler and Hammar-Klose, 2000b). Two recent studies, one on land-area change in Louisiana (Barras and others, 2008) and one on sediment compaction and subsidence models (Ivins and others, 2007), are incorporated into the CVI ranking system and used to calculate an updated CVI for the Northern Gulf of Mexico. Because the Ivins and others (2007) vertical movement model is more closely linked to the geologic variability of the region than the water-level recorders, which provide only sparse coverage along the Mississippi Delta, the Ivins and others (2007) dataset was chosen as the relative SLR data source for the updated Northern Gulf of Mexico CVI. Vertical movement rates based on Ivins and others (2007) are ranked such that rates above $5 \mathrm{~mm} / \mathrm{yr}$ are very high vulnerability, and increasingly lower vertical movement rates are lower vulnerability. Land area change data are based on Barras and others (2008) data from 1956 to 2008 and are used as an alternative to shoreline change data for wetlands and salt marshes in Louisiana. Land loss rates are in square meters per kilometer per year $\left(\mathrm{m}^{2} / \mathrm{km}^{2} / \mathrm{yr}\right)$ and are derived from 13 classified Landsat Thematic Mapper satellite mosaics and 3 national wetland inventory habitat datasets over the last 50 years. Landarea change rates were calculated at 5-km intervals within the Louisiana coastal area (Barras and others, 2008). Ranked-land area change rates are shown in table 2. 
Table 2. Ranges for vulnerability ranking of variables along the Northern Gulf of Mexico Coast.

\begin{tabular}{|c|c|c|c|c|c|}
\hline Variables & $\begin{array}{c}\text { Very Low } \\
1\end{array}$ & $\begin{array}{l}\text { Low } \\
2\end{array}$ & $\begin{array}{c}\text { Moderate } \\
3\end{array}$ & $\begin{array}{l}\text { High } \\
4\end{array}$ & $\begin{array}{l}\text { Very High } \\
5\end{array}$ \\
\hline Geomorphology & $\begin{array}{l}\text { Rocky cliffed } \\
\text { coasts, fjords }\end{array}$ & $\begin{array}{l}\text { Medium } \\
\text { cliffs, } \\
\text { indented } \\
\text { coasts }\end{array}$ & $\begin{array}{l}\text { Low cliffs, } \\
\text { glacial drift, } \\
\text { alluvial plains }\end{array}$ & $\begin{array}{l}\text { Cobble } \\
\text { beaches, } \\
\text { estuary, } \\
\text { lagoon }\end{array}$ & $\begin{array}{l}\text { Barrier beaches, } \\
\text { sand beaches, } \\
\text { salt marsh, mud } \\
\text { flats, deltas, } \\
\text { mangrove, coral } \\
\text { reefs }\end{array}$ \\
\hline $\begin{array}{l}\text { Shoreline erosion/accretion } \\
\text { (meters per year) }\end{array}$ & $>2.0$ & $1.0-2.0$ & $-1.0-1.0$ & $-2.0--1.0$ & $<-2.0$ \\
\hline $\begin{array}{l}\text { Land-area change (square } \\
\text { meters per square kilometer } \\
\text { per year) }\end{array}$ & $>1000$ & $0-1000$ & $-1000--1$ & $-2000-1001$ & $<-2000$ \\
\hline Coastal slope (percent) & $>1.20$ & $1.20-0.90$ & $0.90-0.60$ & $0.60-0.30$ & $<0.30$ \\
\hline $\begin{array}{l}\text { Relative sea-level change } \\
\text { (millimeters per year ) }\end{array}$ & $<1.8$ & $1.8-2.5$ & $2.5-3.0$ & $3.0-3.4$ & $>3.4$ \\
\hline $\begin{array}{l}\text { Vertical movement } \\
\text { (millimeters per year) }\end{array}$ & $<1.1$ & $1.1-2.4$ & $2.5-3.9$ & $4.0-5.0$ & $>5.0$ \\
\hline $\begin{array}{l}\text { Mean significant wave height } \\
\text { (meters) }\end{array}$ & $<0.55$ & $0.55-0.85$ & $0.85-1.05$ & $1.05-1.25$ & $>1.25$ \\
\hline Mean tidal range (meters) & $>6.0$ & $4.0-6.0$ & $2.0-3.99$ & $1.0-1.99$ & $<0.99$ \\
\hline
\end{tabular}




\section{Calculating the index}

The coastal vulnerability index (CVI) calculated in this study is the same as that used in Thieler and Hammar-Klose (1999) and is similar to that used in Gornitz and others (1994), as well as to the sensitivity index employed by Shaw and others (1998). Once each section of coastline is assigned a ranked value for each specific data variable, the CVI is calculated as the square root of the product of the ranked variables divided by the total number of variables:

$$
C V I=\sqrt{(a \times b \times c \times d \times e \times f) / 6}
$$

where

$a$ = geomorphology,

$b=$ shoreline erosion/accretion rate (or land area loss),

$c=$ coastal slope,

$d$ =relative sea-level rise rate (or vertical movement rate),

$e=$ mean significant wave height, and

$f=$ tidal range.

The calculated CVI value is then divided into four vulnerability categories, which are defined such that each interval is statistically different from the adjacent interval (that is, natural Jenks). This method of establishing vulnerability ranges is different from the quintile ranges established by Thieler and Hammar-Klose (2000b), and focuses on grouping similar values and maximizes the differences between vulnerability groups. The CVI ranges (low - very high) defined in this report apply specifically to the Northern Gulf of Mexico and are not comparable to CVI ranges in other areas where the CVI has been employed (that is, very high vulnerability means the same among regions, but the numeric values differ, such that a numeric value that equals very high vulnerability in one region may equal moderate vulnerability in another). To compare CVIs between regions, the national-scale studies should be used (Thieler and Hammar-Klose, 1999; 2000a; and 2000b).

\section{Principal component analysis}

The variables defining the CVI are not independent or random; therefore they do not contribute equally to the unweighted index. A principal component analysis (PCA) is utilized to reduce the dimensionality of the CVI data, illustrate the relationships that exist among variables, identify the relative importance of each variable, and help to understand variable importance along the coast. PCA is performed on the CVI, calculated such that five variables are held at the mean and one variable is allowed to change. This isolates individual variables and returns the contribution of each variable within a principal component. Eigenvectors and principal component loadings, which are coefficients of the equation that defines the eigenvector and corresponds to a variable, are then used to determine which variable or combination of variables is most influential to the index value, and which variables are least influential (appendix).

\section{Geologic Variables}

\section{Geomorphology}

The geomorphology variable expresses the relative erodibility of different landform types (table 2). These data were derived using aerial photography, land cover data, Google Earth ${ }^{\mathrm{TM}}$, and Coastal 
Classification Atlases (Morton and others, 2004, 2005; Morton and Peterson, 2005a-c) (table 1). Geomorphologic landforms within the study area include high vulnerability lagoons and estuaries and very high vulnerability sandy beaches, saltmarshes, barrier islands, and tidal flats (fig. 4). Very high vulnerability landform types account for 85 percent of the assessed shoreline. Areas classified as high vulnerability (15 percent) include Lake Borgne and Lake Pontchartrain and the mainland coast of Mississippi and Alabama.

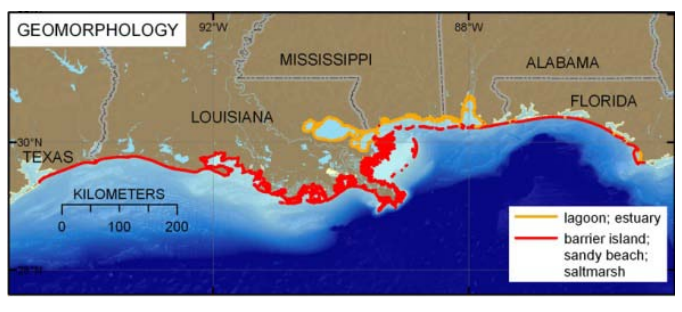

Figure 4. Coastal geomorphology for the Northern Gulf of Mexico. The colored shoreline represents the variations in coastal geomorphology along the coast. The very high vulnerability geomorphology (red) includes barrier islands, saltmarshes, tidal flats, and sand beaches, whereas high vulnerability areas (orange) include estuaries and lagoons.

\section{Historical shoreline change rate}

Several historical shoreline change rate databases are available for the Northern Gulf of Mexico (Dolan and others, 1985; Miller and others 2004; and Martinez and others, 2006). The Dolan and others (1985) dataset was constructed using a coastal erosion information system (CEIS), which was based on numerous data sources and resolutions, and was the only available dataset when the original Gulf of Mexico CVI was produced (Thieler and Hammar-Klose, 2000b). The Miller and others (2004) dataset covers sandy beaches and barriers for all of the Gulf of Mexico, and their historical change rates are based on a linear regression every $50 \mathrm{~m}$ for four shorelines between the late 1800s and 2002 (fig. 5B). Connor and others (2004) produced shoreline change rates for coastal Louisiana by dividing the shore into 80 reaches, generally between 3 and $40 \mathrm{~km}$ in length, based on geomorphology, change trends, and shoreline engineering practices. Martinez and others (2006) expanded the shoreline change coverage for the Gulf Coast of Louisiana originally published by Connor and others (2004), to include the birdfoot and Atchafalaya Bay (fig. 5C). The Dolan and others (1985) estimates of shoreline erosion and accretion cover the entire U.S. coastline, which represents shoreline change rates on a regional scale $(1: 7,500,000)$ (fig. 5A). The shoreline change data produced by Miller and others (2004) and Martinez and others (2006), provide a high resolution alternative to the 1:7,500,000 shoreline change dataset of Dolan and others (1985). Although these higher resolution datasets are not available in wetland areas or along the mainland coast of Mississippi and Alabama, they are a more current dataset at a more useful scale for CVI assessments and should be included whenever possible to increase CVI resolution. Figure 5A-C shows the shoreline change data availability and distribution along the Northern Gulf of Mexico coast. 


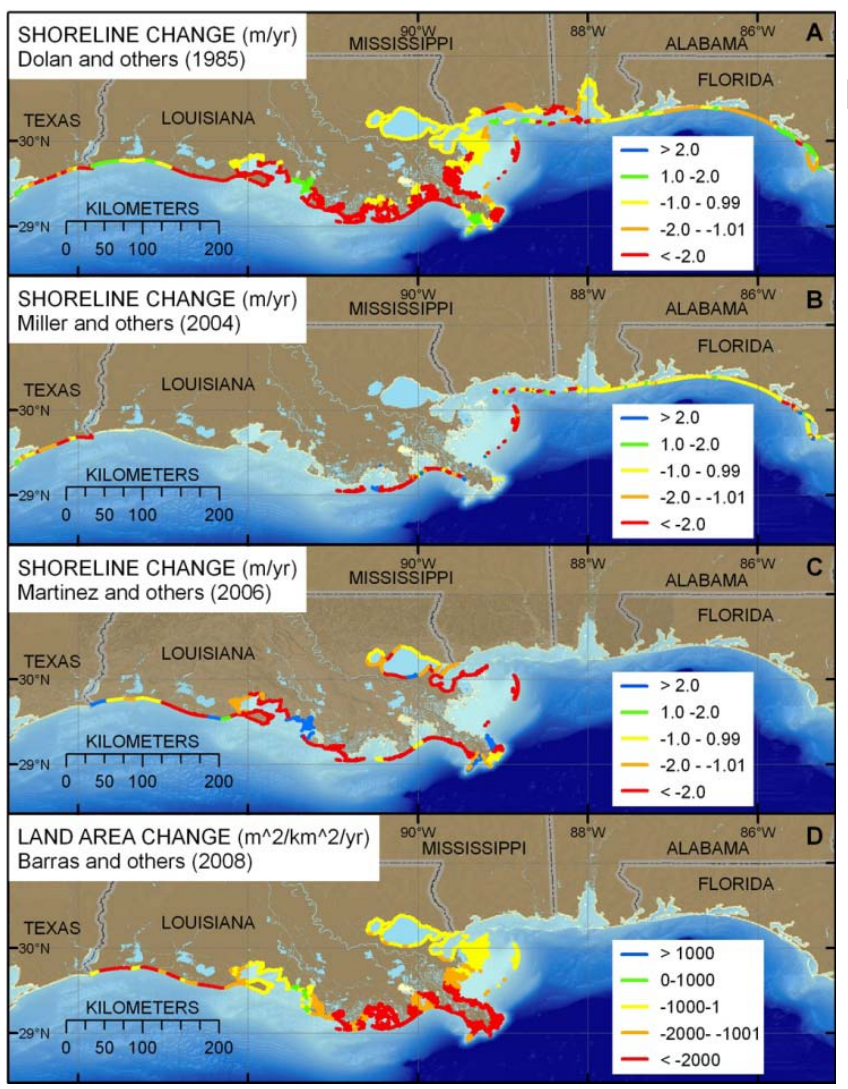

Figure 5. Shoreline change and land-area change datasets available within the Northern Gulf of Mexico study area. $(A)$ The Dolan and others (1985) dataset is the most comprehensive and the lowest resolution. It is displayed here as it was categorized by Thieler and Hammar-Kose (2000b). (B) The Miller and others (2004) dataset is available for sandy beaches and barriers along the Gulf of Mexico at 50-meter intervals. (C) The Martinez and others (2006) dataset is for the Gulf Coast of Louisiana.(D) The Barras and others (2008) land-area change data are for Louisiana barriers as well as marsh areas.

\section{Historical land-loss rate}

Large wetland areas cannot be quantified with regard to shoreline erosion and accretion through the use of traditional mean high water line delineation and linear regression techniques. In order to investigate vulnerability for the vast wetland stretches of Louisiana, the traditional CVI methodology (Theiler and Hammar-Klose, 2000b) is modified to include land-loss data produced by Barras and others (2008). These data represent inland and coastal wetland loss from 1956 to 2008 (fig. 5D). These data are incorporated into the CVI in much the same way as the historical shoreline change studies are included. The main difference is that land loss data are measured in terms of area change rather than length. The Barras and others (2008) land-area change dataset provides a quantitative and novel approach to delineating land loss rates in Louisiana wetland areas, where traditional shoreline change determinations cannot be made. These data provide a long-term record (1956-2008) of land-area change that can be incorporated into the CVI.

\section{Regional coastal slope}

Coastal slope is an indication of vulnerability to inundation and the potential rapidity of shoreline retreat because low-sloping coastal regions should retreat faster than steeper regions (Pilkey and Davis, 1987). The regional slope (percent) of the coastal zone was calculated from a grid of topographic and bathymetric elevations extending in a 10-km radius, landward and seaward, of the shoreline. Elevation data were obtained from the National Geophysical Data Center (NGDC) as gridded topographic and bathymetric elevations at 0.1-meter vertical resolution and 3-arc second horizontal resolution (Divins and Metzger, 2009). These data also mark a resolution improvement over the original Gulf of Mexico CVI (Thieler and Hammar-Klose, 2000b) (fig. 1), wherein slopes were based on ETOPO-2 elevation data (U.S. Department of Commerce, 2006). Regional coastal slopes for the 
Northern Gulf of Mexico range from the very low to the very high vulnerability category $(<0.3 \%$ $>1.2 \%$ ); however, the very high vulnerability regional slope category (slope $<0.3 \%$ ) represents 86 percent of the total assessed shoreline (fig. 6).

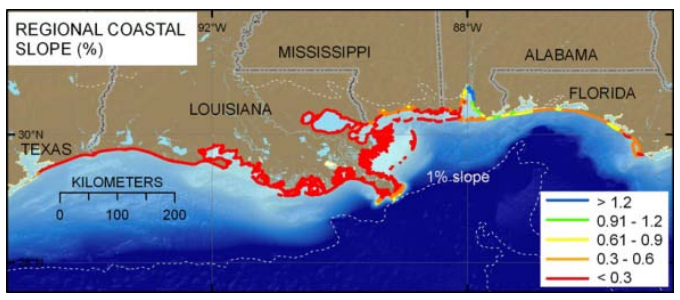

Figure 6. Regional coastal slope for the Northern Gulf of Mexico. The colored shoreline represents the regional slope of the land in a $10-\mathrm{km}$ radius of the shoreline. Very low vulnerability slope areas are along Mobile Bay. Coastal slopes become gentler away from Mobile Bay and thus higher in vulnerability with respect to the CVI ranking scheme (table 2).

\section{Physical Process Variables}

\section{Relative sea-level change}

The relative sea-level change variable is derived from the change in annual mean water elevation over time as measured at tide gage stations along the coast. There are 16 tide gauges with records longer than 25 years between Key West, FL, and Port Isabel, TX (NOAA/NOS/CO-OPS, 2009; Zervas, 2001). The change in the rate of sea-level rise along the coast was estimated by gridding sea-level rise rates from these 16 tide stations using a linear interpolation method. Tide gauge data inherently include both eustatic sea-level change as well as regional sea-level change due to isostatic and tectonic adjustments of the land surface. Relative sea-level change data are a historical record and thus portray only the recent sea-level trend ( $<100$ years). Relative sea-level change for the northern Gulf of Mexico falls within the very low $(1.38 \mathrm{~mm} / \mathrm{yr}$ at Apalachicola, FL) to very high vulnerability $(9.65 \mathrm{~mm} / \mathrm{yr}$ at Eugene Island, LA) category based on tide gauge data (fig. 7). Using the ranking scheme outlined in table 2 and that of Thieler and Hammar-Klose (2000b), 88 percent of the northern Gulf of Mexico falls within the very high vulnerability category with respect to sea-level rise.

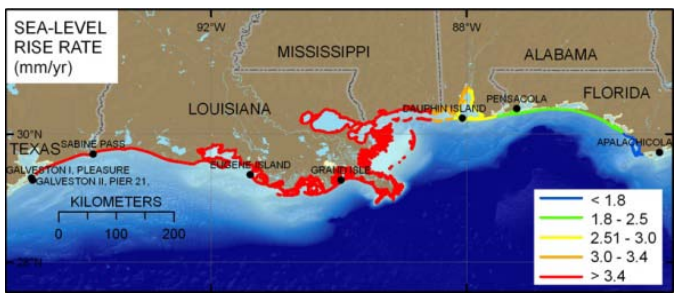

Figure 7. Relative sea-level change rate along the Northern Gulf of Mexico. Eight of the 16 tide gage locations along the U.S. Gulf of Mexico coast fall within the study area and are indicated by black dots.

\section{Vertical movement rate}

In addition to sea-level rise rates determined from tide gauge data, vertical movement rates have been estimated for the Northern Gulf of Mexico using GPS measurements, Holocene sediment thicknesses, and a viscoelastic Earth model (Ivins and others, 2007). These data suggest vertical movement rates, as a result of subsidence, to be between -1 and $-6 \mathrm{~mm} / \mathrm{yr}$ from Pensacola, FL, to Galveston, TX (fig. 8A and $8 B$ ). These data can be divided into categories in a similar way that the tide gauge SLR data are classified (table 2). The distribution of vertical movement rate may capture more of the variability in subsidence rates that exists across the study area as a result of sediment loading and compaction of the Mississippi Delta sediments than the relatively sparse water-level recorders are able to capture (that is, there are only 7 tide gauges with a record longer than 20 years from Apalachicola, 
FL, to Galveston, TX) (fig. 8B). In addition, Between the Grand Isle, LA, and Dauphin Island, AL tide gages, there is more than $6,000 \mathrm{~km}$ of shoreline (as measured using the GSHHS for this study) and more than 6-mm/yr difference in sea-level rise rate. The update from sea-level rise rate to vertical movement rate highlights important differences in relative sea-level change between the Mississippi Delta and the barrier coasts of Florida and Texas, and thus is chosen to replace the NOS tide gage data in the updated CVI determination. Using vertical movement rate data, 51 percent of the study area is very high vulnerability, as opposed to 88 percent when water-level recorders are the sea-level change data.
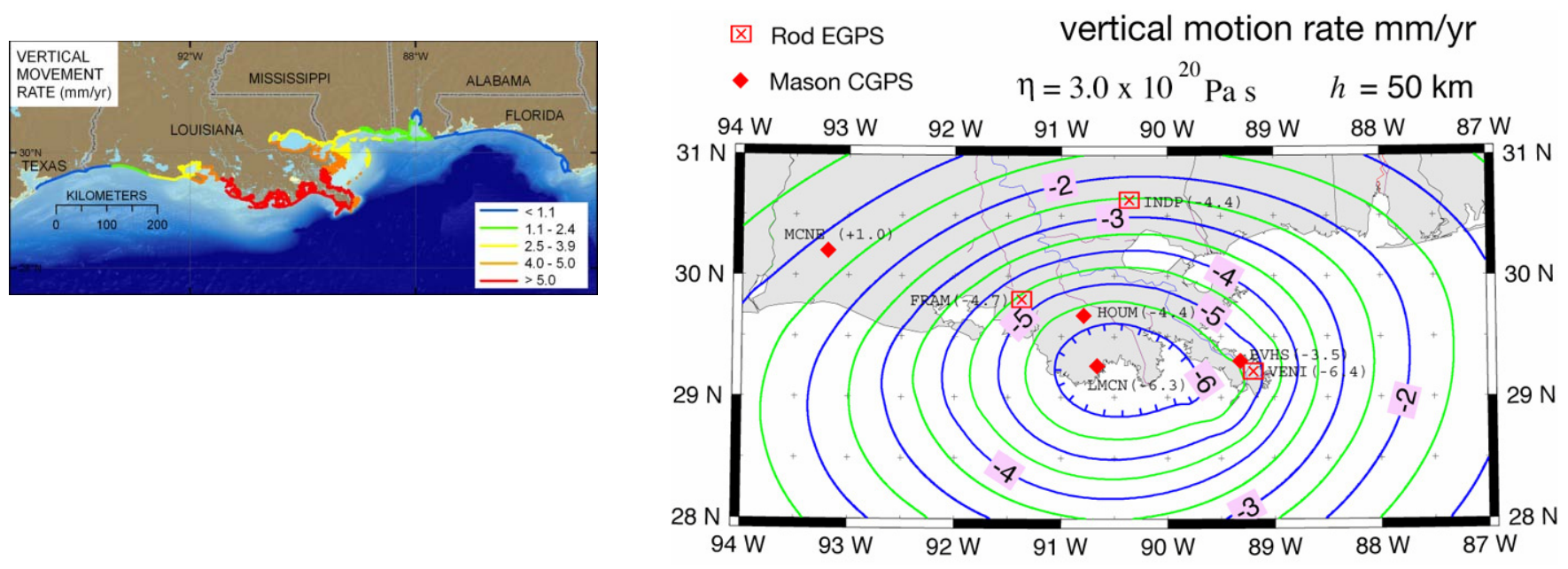

Figure 8. (A) Vertical movement rate along the Northern Gulf of Mexico (after Ivins and others, 2007). The red dots and x's represent GPS locations. (B) Vertical movement rate along the Northern Gulf of Mexico divided into quintiles for $\mathrm{CVI}$ variable ranking (table 2).

\section{Mean significant wave height}

Mean significant wave height is used here as a proxy for wave energy, which drives coastal sediment transport. Wave energy is directly related to wave height

$$
\mathrm{E}=1 / 8 \rho \mathrm{gH}^{2}
$$

where

$\mathrm{E}$ is energy density,

$\mathrm{H}$ is significant wave height,

$\rho$ is water density, and

$\mathrm{g}$ is acceleration due to gravity.

The ability to mobilize and transport coastal sediments is a function of wave height squared. Hindcast significant wave height data are available for the Gulf of Mexico using the U.S. Army Corps of Engineers Wave Information Study (WIS) (Hubertz and others, 1996). These data were gridded using an interpolation method to derive continuous wave height data for the open coast of the Gulf of Mexico. Mean significant wave heights in the Northern Gulf of Mexico ranged from greater than $0.7 \mathrm{~m}$ along the open Gulf of Mexico coast of Texas and Louisiana to $0.6 \mathrm{~m}$ along the Florida open Gulf coast. Wave 
heights within bays, lagoons, estuaries, and sheltered saltmarshes are less that $0.5 \mathrm{~m}$ (very low mean significant wave height vulnerability), and represented over 70 percent of the evaluated shoreline with respect to wave height (fig. 9).

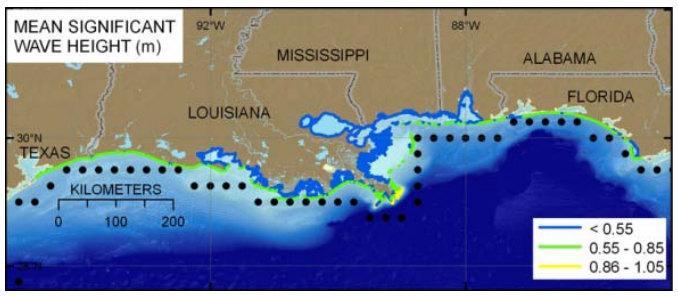

Figure 9. Mean significant wave height (meters) along the Northern Gulf of Mexico. The black dots indicate the locations of WIS wave stations (Hubertz and others, 1996).

\section{Tidal Range}

Tidal range is linked to both permanent and episodic inundation hazards. Tide range data were obtained from NOAA/NOS published benchmarks from the Gulf of Mexico. Mean tidal range is less than $1 \mathrm{~m}$ for all of the Northern Gulf of Mexico; therefore, the entire shoreline (100\%) was classified as very high vulnerability $(0-1.0 \mathrm{~m})$ with respect to tidal range.

\section{Results}

A CVI for the Northern Gulf of Mexico is calculated using NOS tide gages (Zervas, 2001) and Dolan and others (1985) shoreline change data in order to create a baseline of comparison for the updated CVI, which will replace NOS tide gage SLR rates with vertical movement rates (Ivins and others, 2007) and the Dolan and others (1985) shoreline change data with updated shoreline change (Miller and others, 2004; Martinez and others, 2006) and land-area loss rates (Barras and others, 2008). The calculated CVI values for the Northern Gulf of Mexico based on NOS/NOAA water-level recorders for sea-level rise rate (Zervas, 2001), geomorphology, shoreline change from Dolan and others (1985), wave height, coastal slope, and tidal range are between 5.16 to 39.53 (fig. 10). The mean CVI value is 20.96; the mode and median are both 22.82. The standard deviation is 6.63. If the CVI is recalculated for the same area based on vertical movement rates from Ivins and others (2007) in place of sea-level rise data from tide gages, shoreline change rates from Miller and others (2004), Martinez and others (2006), and land loss rates from Barras and others (2008), while all other variables remain the same, the CVI values are between 3.65 to 35.35 (fig. 11). The mean CVI value is 20.38; the mode and median are 22.82 and 20.41, respectively. The standard deviation is 5.87 .

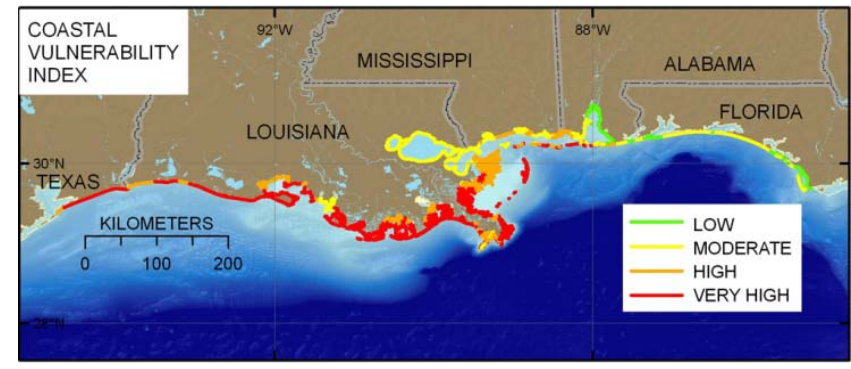

Figure 10. Northern Gulf of Mexico CVI calculated using Dolan and others (1985) shoreline change data and sea-level rise rate from NOS/NOAA water-level gages. 


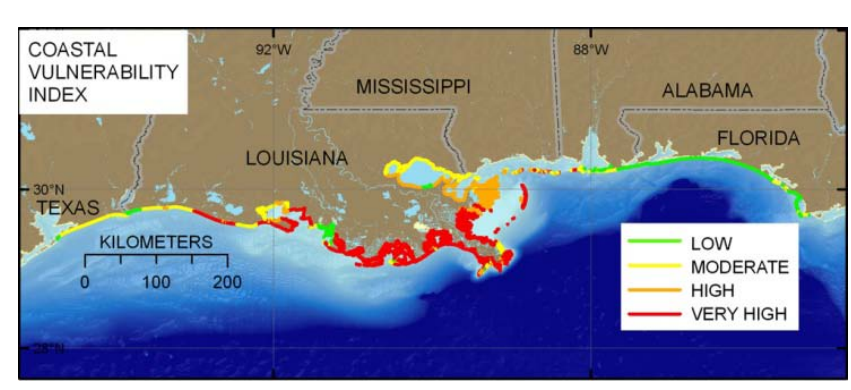

Figure 11. Updated data source CVI calculated using Miller and others (2004), and Martinez and others (2006) shoreline change data, Barras and others (2008) landarea change data, and vertical movement data from Ivins and others (2007).

The CVI scores in figures 10 and 11 are divided into low, moderate, high, and very high vulnerability categories based on the natural breaks in the data as determined from the original (data source) CVI (fig. 10). This was done so that the CVI value ranges were the same between figures, allowing direct comparison. CVI values below 10.95 are assigned to the low vulnerability category. Values from 10.96 to 16.32 are considered moderate vulnerability. High vulnerability values lie between 16.33 and 20.4. CVI values above 20.4 are classified as very high vulnerability. Figure 12 shows the percentage of shoreline in each vulnerability category for figures 10 and 11. Between 10,000 and 11,000 kilometers of shoreline are evaluated in the study area for figures 10 and 11. Of this total, 61 percent of the mapped shoreline is classified as being at very high vulnerability due to future sea-level rise. 16 to 21 percent is classified as high vulnerability, 13 to 15 percent as moderate vulnerability, and 3 to 7 percent as low vulnerability. The updated CVI mean value was less than 3 percent different than the original CVI mean value.

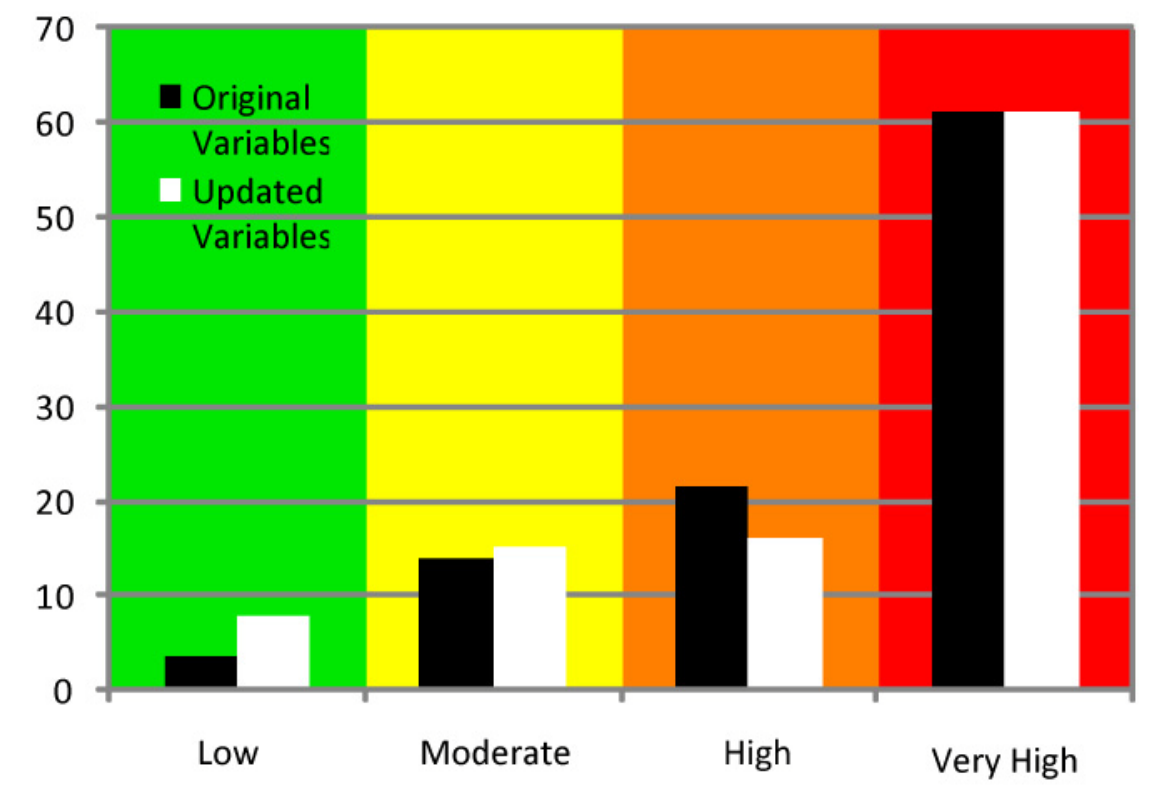

Figure 12. Updated data source CVI calculated using Miller and others (2004), and Martinez and others (2006) shoreline change data, Barras and others (2008) land-area change data, and vertical movement data from Ivins and others (2007). 
In order to determine which variables may be most important to the CVI, a principal component analysis (PCA) was performed on the variables used to calculate the CVI. For both CVIs (figs. 10 and 11), sea-level rise rate or vertical movement rate, shoreline change rate or land-loss rate, and wave height were the three most important variables (appendix). Wave height was most significant in the first principal component for the original data source CVI, while the combination of vertical movement, shoreline change (or land loss), and wave height was important in the updated CVI first principal component. Tidal range did not vary within the entire study area, and therefore did not contribute to the variance in the CVI. Coastal slope and geomorphology were only significant in the 4th and 5th principal components, which explains between 5 and 0.75 percent of the CVI variance, respectively. Appendix contains figures and tables from the principal component analysis of both CVIs.

The areas that were consistently ranked as very high vulnerability among CVI determinations include the coastal areas surrounding Barataria Bay, Terrebonne Bay, and the Chandeleur Islands. The Atchafalaya Bay region was consistently ranked as moderate to low vulnerability, as was much of the Florida panhandle. Lake Pontchartrain and Lake Borgne generally ranked from moderate to high vulnerability. The areas that varied the most between CVI determinations were the Chenier Plain in Western Louisiana and Texas, and the Mississippi-Alabama barrier island chain.

\section{Discussion}

While the methodology and data sources of Thieler and Hammar-Klose (2000b) (fig. 10) were used to generate an initial CVI for the Northern Gulf of Mexico in this report, recent studies have also been utilized to update variables within the CVI framework without significantly altering the methodology. Updates to the original CVI datasets include: a change from NOS water-level records to a subsidence and sediment load model (Ivins and others, 2007) for sea-level rise rate, and updates to the shoreline change database to include land-loss data (Barras and others, 2008) for Louisiana and shoreline change along sandy shores (Miller and others, 2004) and the Louisiana Gulf Coast (Martinez and others, 2006). Updated variables for shoreline change and land-loss do not have the same coverage extent as the original CVI; thus a CVI for the entire study area based solely on updates of shoreline change or land-loss rates cannot be produced. However, an updated CVI that accounts for 91 percent of the shoreline in the original variable CVI is calculated with higher resolution data sources. These higher resolution datasets capture local to regional changes in vertical movement, slope, and shoreline and land-area change and improve the resolution and applicability of the CVI assessment. CVI assessments are still limited by the omission of coastal storm information, and the episodic and nonlinear nature of storms makes them difficult to incorporate into the CVI framework. The CVI results presented in this report are an indication of vulnerability based on coastal processes and geologic qualities that are everpresent and predictable and should be used in conjunction with storm vulnerability studies within the region (for example, Stockdon and others, 2007; Fearnley and others, 2009; Doran and others, 2009) in order to obtain the most comprehensive vulnerability assessment.

The update in figure 11 has the same vulnerability ranges as the original data source CVI in figure 10, and there are some similarities and differences between the original and updated source CVIs that are important to point out. The update CVI (fig. 11) ranks the majority of the Mississippi Delta as very high vulnerability, a similar result to the original CVI where the Mississippi Delta is ranked as high to very high vulnerability. While it is not surprising that the Mississippi Delta region is high to very high vulnerability in both determinations, the updated CVI ranks most of the Florida panhandle as low vulnerability. However, in the original source CVI, the Florida panhandle is mostly moderate vulnerability. Furthermore, the updated CVI shows that the Chenier Plain and Texas coast, with low vertical movement rates and low shoreline change rates, may be more vulnerable to sea-level rise than 
the Florida panhandle coast. This difference is likely due in part to slightly larger wave heights off the coast of Texas.

Although the overall differences between the original and the updated CVI for the Northern Gulf of Mexico may be slight, the vulnerability pattern in the updated data source CVI seems to be more consistent with regional geology than was the original CVI. This is especially apparent in the first principal component of the updated CVI, where the direct relationship between sea-level rise and shoreline change or land loss is responsible for nearly half of the CVI variance. In the original CVI, wave height alone is the primary variable in the first principal component, because the lower resolution SLR and shoreline change data do not capture many of the local to regional variations in sea-level and shoreline change.

\section{Conclusions}

Coastal vulnerability index assessments can provide insight into the relative potential of coastal change due to future sea-level rise. The maps and data presented here illustrate the versatility of coastal vulnerability assessments, provide a comparison between original and updated CVIs, and show that updating variable data can increase the quality of these assessments. CVI data can be used in at least two ways: (1) as a way of identifying areas where physical changes are most likely to occur as sea-level rises and (2) as a planning tool for managing and protecting resources along the Northern Gulf of Mexico.

As determined in this study, relative sea-level change, shoreline change or land-loss rate, and wave height are the most important variables in determining a CVI for the Northern Gulf of Mexico. Coastal Louisiana may be the most vulnerable to the effects of future sea-level rise and coastal change in this region, due to the high rates of relative sea-level rise, shoreline change, and land-area change. Data source updates and high resolution datasets for the Northern Gulf of Mexico region have improved the CVI assessment for this region. Datasets that can capture local to regional differences in vertical movement and shoreline and land-area change are extremely valuable to these types of assessments in areas where understanding coastal system change in conjunction with storm vulnerability is essential to hazard mitigation. 


\section{Acknowledgments}

This manuscript benefited from reviews by Erika Lentz and Ben Gutierrez. This CVI assessment was conducted under the USGS Northern Gulf of Mexico (NGOM) Ecosystem Change and Hazard Susceptibility project. Jennifer Martin at the Woods Hole Coastal and Marine Science Center arranged this document to meet USGS HTML format specifications.

\section{References Cited}

Barras, J.A., Bernier, J.C., and Morton, R.A., 2008, Land area change in coastal Louisiana--A multidecadal perspective (from 1956 to 2006): U.S. Geological Survey Scientific Investigations Map 3019, scale 1:250,000, 14 p. pamphlet.

Bindoff, N.L., Willebrand, J., Artale, V. Cazenave, A., Gregory, J., Gulev, S., Hanawa, K., Le Quéré, C., Levitus, S., Nojiri, Y., Shum, C.K., Talley, L.D., and Unnikrishnan, A., 2007, Observations: Oceanic Climate Change and Sea Level, in Solomon, S., Qin, D., Manning, M., Chen, Z., Marquis, M., Averyt, K.B., Tignor, M., and Miller, H.L., eds., Climate Change 2007: The Physical Science Basis. Contribution of Working Group I to the Fourth Assessment Report of the Intergovernmental Panel on Climate Change: Cambridge University Press, Cambridge, United Kingdom, p. 385-432. Connor, P.F.Jr., Penland, S.P., Beall, A.D., Kulp, M.A., Fearnley, S., Williams, S.J., and Sallenger, A.H.Jr., 2004, Long-term Shoreline change history of Louisiana's gulf shoreline: 1800's to 2002: Pontchartrain Institute for Environmental Sciences, PIES_CRL Technical Report Series 04001. Divins, D.L., and Metzger, D., 2009, NGDC Coastal Relief Model, volumes 3 - 5, accessed at http://www.ngdc.noaa.gov/mgg/coastal/coastal.html.

Dolan, Robert., Anders, F.J, and Kimball, Suzette, 1988, Coastal erosion and accretion: National Atlas of the United States of America: U.S. Geological Survey, Reston, Virginia, 1 sheet, scale 1:7,500,000.

Doran, K.S., Plant, N.G., Stockdon, H.F., Sallenger, A.H., Serafin, K.A., 2009, Hurricane Ike: Observations of Coastal Change: U.S. Geological Survey Open-File Report 2009-1061.

Fearnley, S., Miner, M., Kulp, M., Bohling, C., Martinez, L., and Penland, S., 2009, Chapter A. Hurricane impact and recovery shoreline change analysis and historical island configuration-1700s to 2005, in Lavoie, Dawn, ed., Sand resources, regional geology, and coastal processes of the Chandeleur Islands coastal system—an evaluation of the Breton National Wildlife Refuge: U.S. Geological Survey Scientific Investigations Report 2009-5252, p. 7-26.

Gornitz, V.M., and White, T.W., 1992, A coastal hazards database for the U.S. West Coast: Oak Ridge, Tennessee, Oak Ridge National Laboratory (ORNL/CDIAC-60).

Gornitz, V.M., Daniels, R.C., White, T.W., and Birdwell, K.R., 1994, The development of a Coastal Vulnerability Assessment Database: Vulnerability to sea-level rise in the U.S. Southeast: Journal of Coastal Research Special Issue No. 12, p. 327-338.

Hammar-Klose, E.S., and Thieler, E.R., 2001, Coastal vulnerability to sea-level rise, a preliminary database for the U.S. Atlantic, Pacific, and Gulf of Mexico coasts: U.S. Geological Survey, Digital Data Series DDS-68, 1 CD.

Hubertz, J.M., Thompson, E.F., and Wang, H.V., 1996, Wave information studies of U.S. coastlines, Annotated bibliography on coastal and ocean data assimilation: Vicksburg, Mississippi, U.S. Army Corps of Engineers Waterways Experiment Station, WIS Report 36, 31 p.

Ivins, E.R., Dokka, R.K., and Blom, R.G., 2007, Post-glacial sediment load and subsidence in coastal Louisiana: Geophysical Research Letters, v. 34(L16303), 5 p. 
Louisiana Oil Spill Coordinator's Office (LOSCO), 2007, Louisiana GIS Digital Map - May 2007 Compilation DVD: Baton Rouge, LA, 2 DVDs, (accessed at: http://lagic.lsu.edu/geodata/LOSCO/2007_DVD/default_2007DVD.htm)

Martinez, L.A., Penland, S.P., Cretini, F., O'Brien, S.P., Bethel, M., Guarisco, P.M., and Fearnley, S., 2006, Barrier Island Comprehensive Monitoring Program Shoreline Change Analysis - 1800's 2005: Pontchartrain Institute for Environmental Science Map, 1 sheet.

Meehl, G.A., Stocker, T.F., Collins, W.D., Friedlingstein, P., Gaye, A.T., Gregory, J.M., Kitoh, A., Knutti, R., Murphy, J.M., Noda, A., Raper, S.C.B., Watterson, I.G., Weaver A.J. , and Zhao, Z.C., 2007, Global Climate Projections. in Solomon, S., Qin, D., Manning, M., Chen, Z., Marquis, M., Averyt, K.B., Tignor, M., and Miller, H.L., eds., Climate Change 2007: The Physical Science Basis. Contribution of Working Group I to the Fourth Assessment Report of the Intergovernmental Panel on Climate Change: Cambridge University Press, Cambridge, United Kingdom, p.

Miller, T.A., Morton, R.A., Sallenger, A.H., and Moore, L.J., 2004, The National Assessment of Shoreline Change: A GIS compilation of vector shorelines and associated shoreline change data for the U.S. Gulf of Mexico: U.S. Geological Survey Open-File Report 2004-1089, accessed at: http://pubs.usgs.gov/of/2004/1089/.

Milne,G.A., Gehrels, W.R., Hughes, C.W., and Tamisiea, M.E., 2009 Identifying the causes of sea-level change: Nature Geoscience, v. 2, p. 471-478.

Morton, R.A., Peterson, R.L., and Miller, T.L. , 2004, Northwestern Panhandle of Florida Coastal Classification Maps-St. Andrew Bay Entrance Channel to Perdido Pass: U.S. Geological Survey Open-File Report 2004-1217, accessed at: http://pubs.usgs.gov/of/2004/1217/.

Morton, R.A., Peterson, R.L., and Miller, T.L. , 2005, Western Louisiana Coastal Classification MapsLower Mud Lake Entrance Channel to Sabine Pass: U.S. Geological Survey Open-File Report 20051261, accessed at: http://pubs.usgs.gov/of/2005/1261/.

Morton, R.A., and Peterson, R.L., 2005a, Southeastern Louisiana Coastal Classification Maps-Pass Abel to East Timablier Island: U.S. Geological Survey Open-File Report 2005-1003, accessed at: http://pubs.usgs.gov/of/2005/1003/.

Morton, R.A., and Peterson, R.L., 2005b, Southeast Texas Coastal Classification Maps-Sabine Pass to the Colorado River: U.S. Geological Survey Open-File Report 2005-1370, accessed at: http://pubs.usgs.gov/of/2005/1370/.

Morton, R.A. and Peterson, R.L., 2005c, Alabama-Mississippi Coastal Classification Maps-Perdido Pass to Cat Island: U.S. Geological Survey Open-File Report 2005-1151, accessed at: (http://pubs.usgs.gov/of/2005/1151/.

National Oceanic and Atmospheric Administration, National Ocean Service, 2009, Regional Mean Sea Level Trends, accessed January 16, 2010, at http://tidesandcurrents.noaa.gov/sltrends/slrmap.html.

Nicholls, R.J., Wong, P.P. , Burkett, V.R., Codignotto, J.O., Hay, J.E., McLean, R.F., Ragoonaden, S.. and Woodroffe, C.D., 2007, Coastal systems and low-lying areas in Parry, M.L., Canziani, O.F., Pauutikof, J.P., van der Linden, P.J., and Hanson, C.E., eds., Climate Change 2007: Impacts, Adaptation and Vulnerability. Contribution of Working Group II to the FourthAssessment Report of the Intergovernmental Panel on Climate Change, pp. 315-356 Cambridge University Press, Cambridge, United Kingdom.

Pendleton, E.A, Thieler, E.R., and Williams, S.J., 2010, Importance of coastal change variables in determining vulnerability to sea- and lake-level change: Journal of Coastal Research, 26(1), p. 176183. 
Pilkey, O.H., and Davis, T.W., 1987, An analysis of coastal recession models, North Carolina coast, in Nummedal, D., Pilkey, O.H., and Howard, J.D., eds., Sea-level fluctuation and coastal evolution: SEPM (Society for Sedimentary Geology) Special Publications no. 41, Tulsa, Okla., p. 59-68.

Shaw, J., Taylor, R.B., Forbes, D.L., Ruz, M.H., and Solomon, S., 1998, Sensitivity of the Canadian coast to sea-level rise: Geological Survey of Canada Bulletin, 505, 114p.

Soluri, E.A., and Woodson. V.A., 1990, World vector shoreline: International Hydrographic Review, LXVII(1).

Stockdon, H.F., Sallenger, A.H., Holman, R.A, and Howd, P.A., 2007, A simple model for the largescale, spatially-variable coastal response to hurricanes: Marine Geology 238, 1-20.

Thieler, E.R., and Hammar-Klose, E.S., 1999, National assessment of coastal vulnerability to future sealevel ise: Preliminary results for the U.S. Atlantic Coast: U.S. Geological Survey, Open-File Report 99-593, 1 sheet, accessed at: http://pubs.usgs.gov/of/1999/of99-593/.

Thieler, E.R., and Hammar-Klose, E.S., 2000a, National assessment of coastal vulnerability to future sea-level ise: Preliminary results for the U.S. Pacific Coast: U.S. Geological Survey, Open-File Report 00-178, 1 sheet, accessed at: http://pubs.usgs.gov/of/2000/of00-178/.

Thieler, E.R., and Hammar-Klose, E.S., 2000b, NNational assessment of coastal vulnerability to future sea-level ise: Preliminary results forthe U.S. Gulf of Mexico Coast: U.S. Geological Survey, OpenFile Report 00-179, 1 sheet, accessed at: http://pubs.usgs.gov/of/2000/of00-179/.

U.S. Department of Commerce, National Oceanic and Atmospheric Administration, National Geophysical Data Center, 2006, 2-minute Gridded Global Relief Data (ETOPO2v2).

Wessel, P., and Smith, W.H.F. , 1996, A global self-consistent, hierarchical, high-resolution shoreline database: Journal of Geophysical Research, 101(B4) p.8741-8743.

Zervas, C., 2001, Sea level variations of the United States 1854-1999: NOAA Technical Report NOS CO-OPS 36, $201 \mathrm{p}$. 


\section{Appendix}

\section{Principal Component Analysis Data Diagrams and Tables for:}

Original CVI: calcuated using geomorphology, shoreline change rate (Dolan and others, 1985), coastal slope, sea-level rise rate (Zervas, 2001), mean significant wave height, and tidal range.

$\square$ Updated CVI: calcuated using geomorphology, shoreline change rate (Miller and others, 2004; Martinez and others, 2006) and land area loss (Barras and others, 2008), coastal slope, vertical movement rate (Ivins and others, 2007), mean significant wave height, and tidal range. 

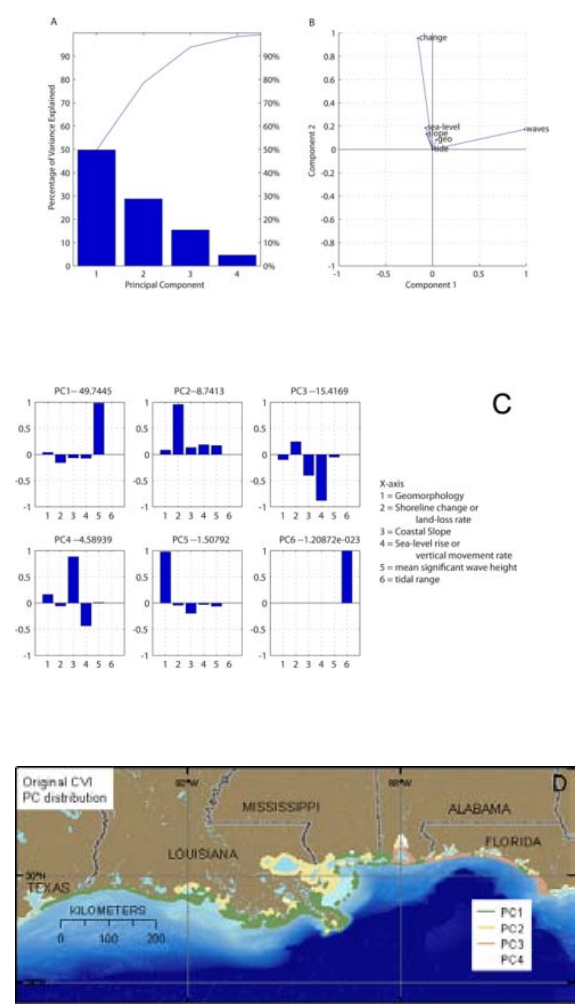

Original CVI: calcuated using geomorphology, shoreline change rate (Dolan and others, 1985), coastal slope, sea-level rise rate (Zervas, 2001), mean significant wave height, and tidal range. 
This table contains the principal component analysis summary for Northern Gulf of Mexico CVI, including eigenvalues and percent of variance explained.

\begin{tabular}{|c|c|c|c|}
\hline $\begin{array}{c}\text { Principal } \\
\text { Component }\end{array}$ & Eigenvalue & $\begin{array}{c}\text { Variance } \\
\text { Explained } \\
\text { (percent) }\end{array}$ & $\begin{array}{c}\text { Total } \\
\text { Variance } \\
\text { (Cumulative } \\
\text { percent) }\end{array}$ \\
\hline 1 & 17.48 & 49.74 & 49.7 \\
\hline 2 & 10.09 & 28.74 & 78.5 \\
\hline 3 & 5.42 & 15.42 & 93.9 \\
\hline 4 & 1.61 & 4.59 & 98.5 \\
\hline 5 & 0.52 & 1.51 & 100.0 \\
\hline 6 & $\begin{array}{c}\text { Approximately } \\
0\end{array}$ & $\begin{array}{c}\text { Approximately } \\
0\end{array}$ & 100.0 \\
\hline
\end{tabular}

(A) The first four principal components (1-4) cumulatively account for more than 99 percent of the variance within the CVI. (B) Biplot of principal components 1 and 2. Note the short vectors corresponding to tidal range, geomorphology, slope, and sea-level rise rate. This plot suggests that only shoreline change and wave height are significant in the first 2 principal components (78.5 percent of the total variance). (C) Bar plots of loadings within each principal component (PC) 1-6; percent of variance explained by each component is shown in the plot title with each principal component. (D) Spatial distribution of the first four principal components, showing where the maximum score (or loading) occurs. This map indicates where each principal component is most influential in determining the CVI. 

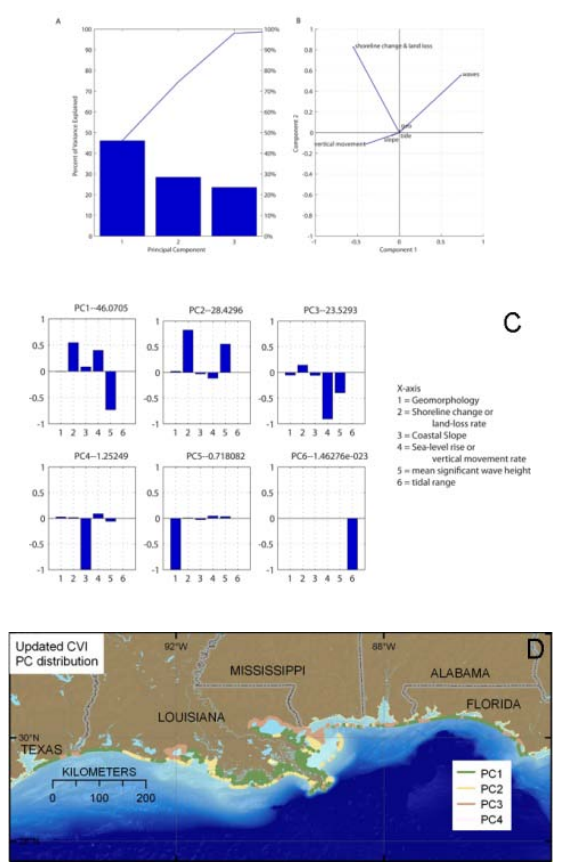

Updated CVI: calculated using geomorphology, shoreline change rate (Miller and others, 2004; Martinez and others, 2006) and land loss (Barras and others, 2008), coastal slope, vertical movement rate (Ivins and others, 2007), mean significant wave height, and tidal range. 
This table contains the principal component analysis summary for Northern Gulf of Mexico CVI, including eigenvalues and percent of variance explained.

\begin{tabular}{|c|c|c|c|}
\hline $\begin{array}{c}\text { Principal } \\
\text { Component }\end{array}$ & Eigenvalue & $\begin{array}{c}\text { Variance } \\
\text { Explained } \\
\text { (percent) }\end{array}$ & $\begin{array}{c}\text { Total } \\
\text { Variance } \\
\text { (Cumulative } \\
\text { percent) }\end{array}$ \\
\hline 1 & 20.49 & 46.07 & 46.07 \\
\hline 2 & 12.65 & 28.43 & 74.5 \\
\hline 3 & 10.47 & 23.53 & 98.03 \\
\hline 4 & 0.56 & 1.25 & 99.28 \\
\hline 5 & 0.31 & 0.72 & 100.0 \\
\hline 6 & $\begin{array}{c}\text { Approximately } \\
0\end{array}$ & $\begin{array}{c}\text { Approximately } \\
0\end{array}$ & 100.0 \\
\hline
\end{tabular}

(A) The first four principal components (1-4) cumulatively account for more than 99 percent of the variance within the CVI. (B) Biplot of principal components 1 and 2. Note the short vectors corresponding to tidal range, geomorphology, slope, and sea-level rise rate. This plot suggests that only shoreline change and wave height are significant in the first 2 principal components (78.5 percent of the total variance). (C) Bar plots of loadings within each principal component (PC) 1-6; percent of variance explained by each component is shown in the plot title with each principal component. (D) Spatial distribution of the first four principal components, showing where the maximum score (or loading) occurs. This map indicates where each principal component is most influential in determining the CVI. 